\title{
Peningkatan potensi mitigasi bencana dengan penguatan kemampuan literasi kebencanaan pada masyarakat Kota Langsa
}

\author{
Ramdan Afrian*, Zukya Rona Islami* \\ * Pendidikan Geografi, FKIP, Universitas Samudra
}

\begin{tabular}{l}
\hline \hline INFO ARTIKEL \\
\hline Riwayat Artikel: \\
Dikirim: $27-9-2018$ \\
Disetujui: $11-3-2019$ \\
Diterbitkan: $30-6-2019$ \\
\hline
\end{tabular}

\section{Kata kunci:}

Literasi, Literasi Informasi

Kebencanaan, Banjir,

Gampong, Kesiapsiagaan

\section{Alamat Korespondensi: \\ Ramdan Afrian \\ Pendidikan Geografi \\ Universitas Samudra}

\begin{abstract}
ABSTRAK
Abstract: This research aimed to enhance the ability of disaster information literacy for the community of Langsa. The method used in this research was an experiment. The method population of the research was the citizens of Gampong Java and Meurandeh totaled 11904 inhabitants. Research samples obtained by purposive sampling technique. Total sample of $15 \%$ of the population was 1786 people. The data were analyzed using a statistical test based on the average (mean) of each variable.The result shows that the process of improving information literacy of disaster brings an increase in familiarity with the community's preparedness against disasters and floods. It proved to be on improving the ability of the population in identifying and evaluating the factors that cause the occurrence of floods. The community began to be able to integrate the information flood-related information. Apart from that, the community has also wished to plan a village emergency response scheme for floods
\end{abstract}

\begin{abstract}
Abstrak: Penelitian ini bertujuan untuk memecahkan permasalahan mengenai kemampuan literasi kebencanaan masyarakat Kota Langsa. Metode penelitian adalah eksperimen. Populasi penelitian adalah warga Gampong Jawa dan Meurandeh berjumlah 11.904 jiwa. Sampel penelitian diperoleh melalui teknik purposive sampling. Jumlah sampel $15 \%$ dari populasi adalah 1.786 orang. Data dianalisis menggunakan uji statistika berdasarkan rata-rata (mean) dari masing-masing variabel. Hasil dari penelitian menunjukkan bahwa proses peningkatan literasi informasi kebencanaan membawa peningkatan kepahaman dan kesiapsiagaan masyarakat terhadap bencana banjir. Hal tersebut terbukti pada peningkatan kemampuan masyarakat dalam mengidentifikasi dan mengevaluasi faktor-faktor yang menyebabkan terjadinya banjir. Masyarakat mulai dapat mengintegrasikan informasiinformasi terkait bencana banjir. Selain itu, masyarakat juga berkeinginan untuk melakukan perancangan skema tanggap darurat Gampong terhadap bencana banjir.
\end{abstract}

This is an open access article under the CC-BY-SA license.

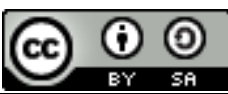


Jurnal Pendidikan Geografi:

Kajian, Teori, dan Praktik dalam Bidang Pendidikan dan Ilmu Geografi

Tahun 24, Nomor 2, Jun 2019, Hal 132-144

Kota Langsa, Aceh

E-mail: ramdan.afrian_geo@unsam.ac.id

\section{PENDAHULUAN}

Ancaman bencana alam di Aceh, yang sering terjadi adalah bersifat hidro-meteorologi seperti banjir, angin puting beliung, dan kekeringan, dan yang bersifat geologi seperti gempa bumi, tsunami, letusan gunung api, dan tanah longsor. Hal ini disebabkan oleh keadaan geografis dan geologis Aceh. Keadaan geografis Aceh mempengaruhi keadaan cuaca dan iklim. Letak geografi tersebut membuat kondisi iklim di Aceh sangat dipengaruhi oleh angin musim Indo-Australia. Kondisi ini membuat wilayah Aceh memiliki karakteristik temperatur udara tinggi serta curah hujan tinggi. Tingginya temperatur dan curah hujan di wilayah Aceh mengakibatkan Aceh memiliki tingkat kompleksitas hidro-meteorologis yang cukup tinggi.

Aceh merupakan daerah yang sangat rawan akan bencana. WALHI (Boy, 2018) mengatakan bahwa "Aceh diketahui daerah langganan banjir tahunan tersebut adalah Aceh Besar, Aceh Jaya, Aceh Barat, Nagan Raya, Aceh Selatan, Singkil, Pidie, Pidie Jaya, Bireuen, Aceh Utara, Aceh Timur, Langsa, Aceh Tamiang, dan Bener Meriah. Sementara tiga kabupaten yang langganan longsor parah adalah Aceh Besar, Bener Meriah dan Aceh Tenggara." (Gambar 1). Dari Gambar 1 dapat dilihat bahwa daerah yang tingkat rawan banjir tinggi berada di Banda Aceh, Kabupaten Aceh Besar, Aceh Utara, Aceh Timur, Langsa, dan Aceh Tamiang. Kota Langsa yang terletak di pesisir pantai timur Provinsi Aceh merupakan hasil pemekaran wilayah dari Kabupaten Aceh Timur. Kota Langsa memiliki titik koordinat antara $04^{\circ} 24^{\prime}-35,68^{\prime}-04^{\circ} 334^{\prime} 0-0,3^{\prime} \mathrm{LU}$ dan $97^{\circ} 53^{\prime} 14,5^{\prime} 9^{\prime}-98^{\circ} 04^{\prime} 42,16^{\prime} \mathrm{BT}$.

Seperti yang telah dijelaskan di atas, setiap tahunnya Kota Langsa mengalami banjir. Selain itu, terjadi kebakaran, pohon tumbang, puting beliung, dan tanah longsor. Tanggal 19 Desember sampai 26 Desember 2014, Kota Langsa mengalami banjir yang terparah. Hal ini diakibatkan oleh curah hujan yang tinggi dan meluapnya air Sungai Krueng Langsa sehingga menyebabkan tergenangnya hampir seluruh wilayah Kota Langsa yang terdiri dari lima kecamatan yaitu Langsa Timur, Langsa Kota, Langsa Barat, Langsa Baro dan Langsa Lama. Hal ini memaksa masyarakat harus mengungsi ke tempat pengungsian yang telah disediakan oleh pemerintah Kota Langsa melalui BPBD Kota Langsa. Dengan korban yang meninggal dunia 2 jiwa, korban yang mengungsi mencapai $3.411 \mathrm{KK}$, kerusakan berat satu musala dan satu rumah, serta 91 hektar sawah (BPBD Kota Langsa, 2015).

Tahun 2015 Langsa juga mengalami bencana banjir yang merendam sejumlah desa di Kota Langsa (Gambar 2), yakni Gampong Tanjung Putus, Kebun Lama, Seulalah, Sidodadi, Sidoarjo, Meurandeh dan Gampong Baru. Banjir ini disebabkan meluapnya sungai yang ada di kawasan Kota Langsa. Peristiwa ini terjadi pada 30 September 2015 pukul 07.00 WIB (Lintas Nasional, com: 2015). 
Jurnal Pendidikan Geografi:

Kajian, Teori, dan Praktik dalam Bidang Pendidikan dan Ilmu Geografi

Tahun 24, Nomor 2, Jun 2019, Hal 132-144

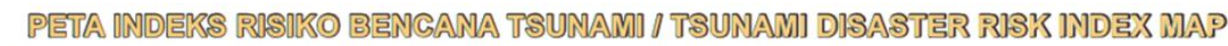

DI PROVINSI NANGGROE ACEH DARUSSALAM / IN NANGGROE ACEH DARUSSALAM PROVINCE

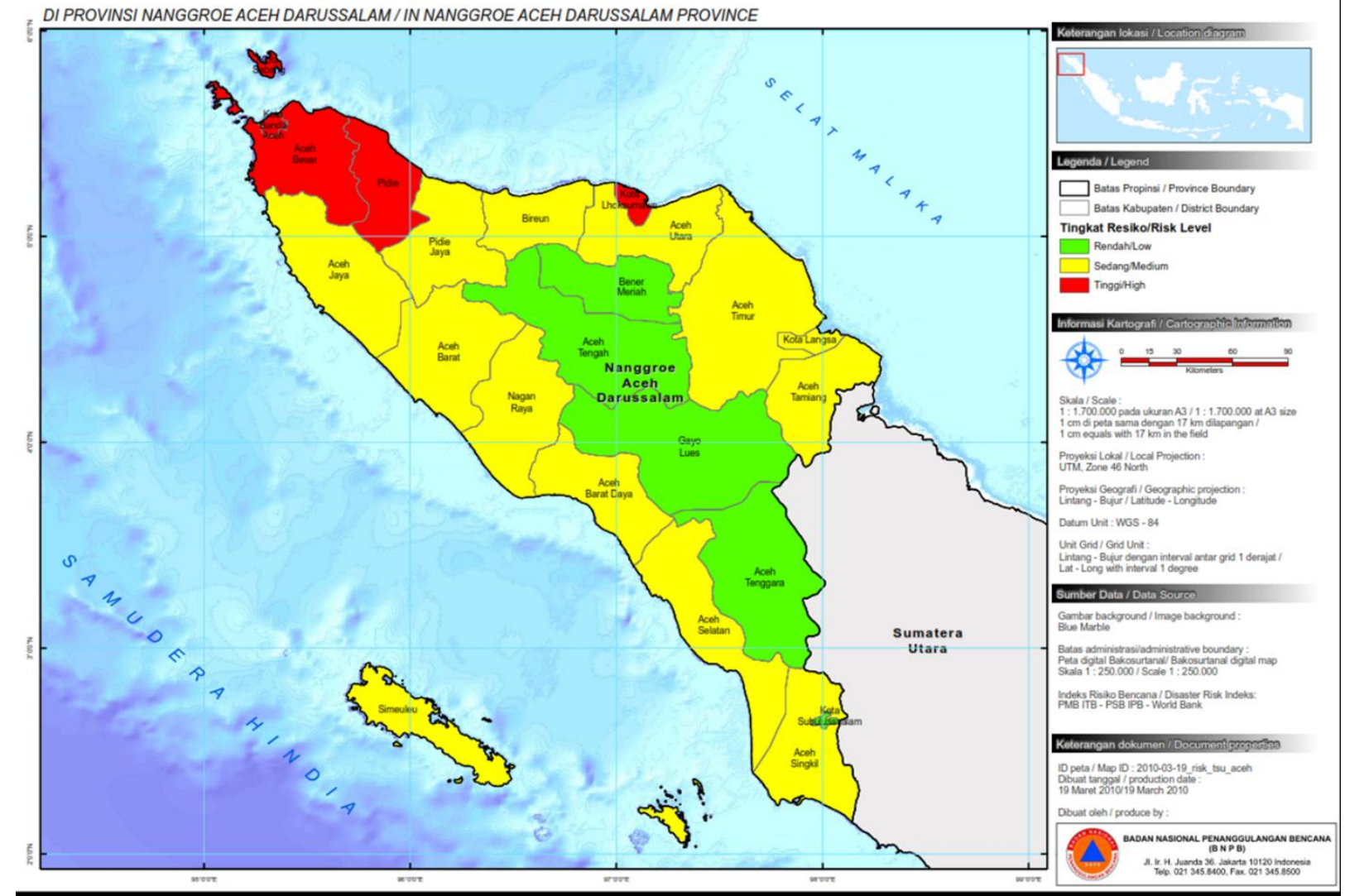

Gambar 1. Peta Indeks Resiko Banjir Provinsi Aceh Sumber:(Badan Nasional Penganggulangan Bencana, n.d.)

Pada tahun 2017, akibat hujan di kawasan pegunungan membuat air sungai meluap, sehingga puluhan rumah di beberapa Gampong Dalam wilayah Kota Langsa terendam banjir (Gambar 2). Puluhan rumah warga yang terendam banjir itu berada di Dusun Cendana dan Melati Dua, Gampong Seulalah Baru dan Dusun Tanjung Jati Satu dan Tanjung Jati Dua, Gampong Seulalah (Induk), serta di Gampong Pondok Pabrik, Kecamatan Langsa Lama (Dedek, 2017).

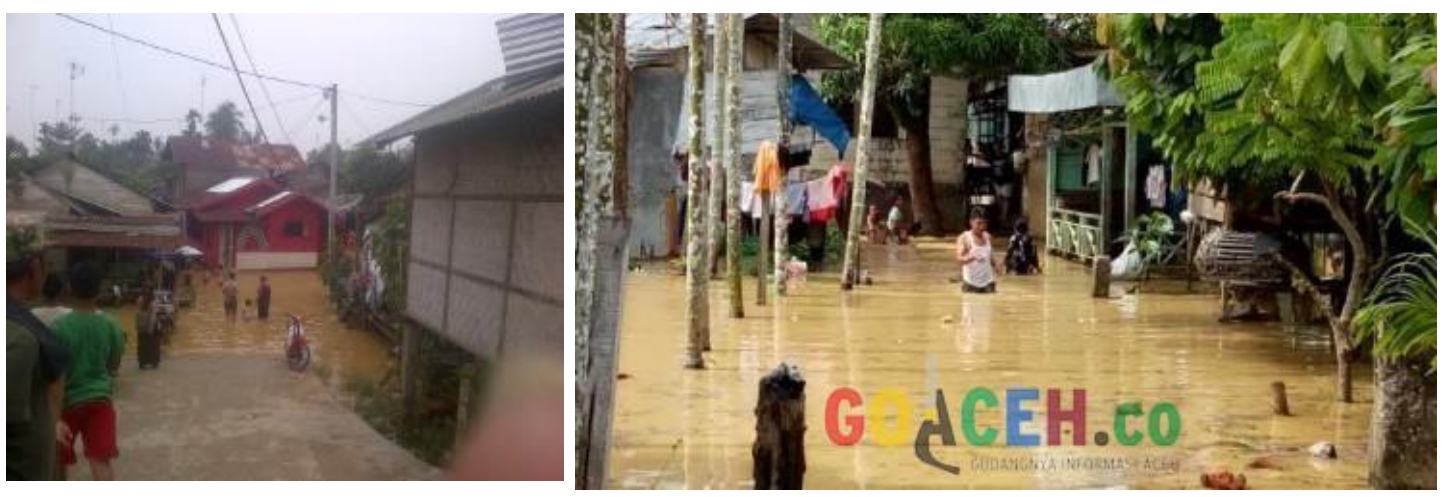

Gambar 2. Dokumentasi keadaan banjir di Kota Langsa Sumber : Lintas Nasional.com dan Go Aceh.co

Penyebab utama banjir memang berasal dari curah hujan yang tinggi. Jika hujan besar turun terus menerus tentu air tidak akan langsung masuk ke saluran pembuangan air, melainkan air yang turun akan menjadi genangan. Genangan air tersebut lama-lama akan 
Jurnal Pendidikan Geografi:

Kajian, Teori, dan Praktik dalam Bidang Pendidikan dan Ilmu Geografi

Tahun 24, Nomor 2, Jun 2019, Hal 132-144

semakin menumpuk dan menjadi banjir. Penyebab lainnya adalah air sungai meluap yang disebabkan tidak lancarnya saluran pembuangan air. Saluran air tidak lancar karena saluran tersebut tersumbat oleh sampah-sampah, sehingga bila curah hujan cukup tinggi dan dalam jangka waktu yang lama, seringkali menyebabkan banjir.

Menurut Strategi Sanitasi Kota Langsa (Umum, 2015) diketahui bahwa limbah, sampah dan drainase di Kota Langsa masih sangat memprihatinkan. Persepsi dari sebagian masyarakat bahwa sarana sanitasi air limbah belum menjadi kebutuhan yang mendesak. Sebagian masyarakat Kota Langsa membuang limbahnya ke sungai dan saluran drainase. Hal tersebut sesuai dengan hasil penelitian Suganda (Suganda, Yatmo, \& Atmodiwirjo, 2009) yang menyatakan bahwa "adanya kebiasaan masyarakat untuk menganggap sungai sebagai tempat pembuangan, baik melalui kebiasaan membuang sampah langsung ke sungai serta kebiasaan menggunakan WC umum dengan pembuangan langsung ke kali”.

Masyarakat sebagai penghasil sampah belum berpartisipasi dalam pengolahan sampah (Yogiesti, Hariyani, \& Sutikno, 2010). Hal ini disebabkan karena kurangnya kesadaran masyarakat tentang pengelolaan sampah. Sering didapati perilaku masyarakat yang membuang sampah secara sembarangan, tidak jarang mereka membuang sampah ke dalam saluran air, termasuk ke dalam Krueng Langsa. Selain itu, belum membudayanya penyediaan bak atau tong-tong sampah dan belum tersedianya lokasi TPS menyebabkan meningkatnya tumpukan sampah di pasar-pasar (Umum, 2015). Permasalahan lain adalah banyaknya drainase yang tersumbat sampah, kios-kios pedagang dibangun di atas drainase, serta ditutupnya saluran dengan plat beton oleh para pemilik toko.

Dari fakta-fakta di atas, terlihat bahwa masyarakat Kota Langsa belum memiliki kesadaran akan resiko bencana banjir yang hampir setiap tahun dialami. Belum ada mitigasi bencana yang baik guna mengurangi resiko bencana banjir tersebut. Banyaknya bencana banjir yang terjadi di Kota Langsa, selayaknya ditanggapi serius oleh berbagai pihak untuk meminimalisir dampak kerugian yang diakibatkan oleh bencana tersebut. Salah satu cara dalam meningkatkan kesiapsiagaan masyarakat adalah dengan peningkatan kemampuan literasi informasi bencana kepada masyarakat.

Literasi bencana atau upaya penyadaran masyarakat dalam menghadapi suatu bencana sangat penting dimiliki oleh masyarakat. Literasi bencana adalah kata kunci yang harus dipahami masyarakat sehingga mereka memahami sepenuhnya (literasi-melek) bahwa letak geografis negerinya berada pada kawasan yang rawan terjadinya bencana. Pendidikan bagi generasi muda menjadi satu faktor penentu dalam kegiatan pengurangan risiko bencana. Adanya pendidikan kebencanaan juga dapat mendorong terwujudnya generasi yang tangguh bencana (Hafida, 2018). Hal tersebut didukung oleh Shah, Ye, Abid, Khan, \& Amir (2018) yang menyatakan "education enhances individual resilience and ability to deal with disaster risks". Oleh karenanya, pengurangan risiko bencana seperti dimandatkan dalam UU Nomor 24 Tahun 2007 tentang Penanggulangan Bencana harus terintegrasi ke dalam program pembangunan pendidikan sehingga mampu melahirkan generasi yang melek bencana (disaster-literate generation). Berdasarkan permasalahan tersebut penelitian ini bertujuan untuk memecahkan permasalahan mengenai kemampuan literasi kebencanaan masyarakat Kota Langsa sehingga dapat meningkatkan potensi mitigasi bencana banjir di Kota Langsa. Asumsi pada penelitian ini yaitu dengan adanya penguatan literasi bencana bagi masyarakat Kota Langsa, maka akan memengaruhi peningkatan mitigasi bencana masyarakat tersebut. Sedangkan lingkup penelitian ini adalah penguatan literasi bencana untuk bencana banjir, sehingga dihasilkan peningkatan kemampuan mitigasi bencana banjir. Lokasi dilakukannya penelitian ini adalah Kota Langsa pada Kecamatan Langsa Lama, Gampong Meurandeh dan pada Kecamatan Langsa Kota, Gampong Jawa. 


\section{METODE}

Metode penelitian yang digunakan dalam penelitian ini termasuk ke dalam Metode penelitian eksperimen. Menurut Creswell (2012) penelitian eksperimen merupakan penelitian untuk menguji suatu ide, praktik atau prosedur untuk menentukan apakah mempengaruhi hasil atau variabel dependen. Eksperimen digunakan untuk membangun kemungkinan sebab akibat antara variabel independen dan variabel dependen. Peneliti mengontrol semua variabel yang memengaruhi hasil kecuali untuk variabel independen. Kemudian, ketika variabel independen mempengaruhi variabel dependen, kita dapat mengatakan variabel independen "penyebab" atau "mungkin disebabkan" variabel dependen.

Bentuk eksperimen dalam penelitian ini berupa pemberian berbagai bentuk media sebagai sarana peningkatan literasi bencana kepada masyarakat terdampak bencana. Tahapan dari eksperimen adalah masyarakat diberikan materi mengenai kebencanaan dalam dua kali pertemuan. Selanjutnya masyarakat diberikan penguatan literasi kebencanaan berupa media-media cetak yaitu komik, pamflet, poster dan leaflet. Semua media ini ditempel di tempat umum yang sering dikunjungi atau dibagikan kepada berbagai kalangan masyarakat dengan tujuan meningkatkan minat baca dan pengetahuan masyarakat.

Objek penelitian ini adalah seluruh warga Gampong Jawa dan Meurandeh sejumlah 11.904 jiwa. Sedangkan sampel penelitian diambil menggunakan teknik purposive sampling. Dengan jumlah sampel 15\% dari populasi yaitu sejumlah 1.786 orang. Pada penelitian ini, peneliti menggunakan sumber data primer berupa angket. Angket yang digunakan adalah angket tertutup. Pertanyaan yang terdiri dari empat pilihan jawaban. Angket digunakan untuk mengetahui literasi kebencanaan masyarakat dalam hal pengetahuan penyebab bencana banjir dan kemampuan evaluasi masyarakat dalam mengatasi banjir. Dalam melakukan pengukuran atas jawaban dari angket-angket tersebut, peneliti menggunakan Skala Likert. Pengolahan data dilakukan dengan editing, koding dan tabulasi. Data dianalisis menggunakan uji statistika berdasarkan rata-rata (mean) dari masing-masing variabel. Setelah didapat rata-rata dari masing-masing variabel, kemudian dibandingkan dengan kriteria yang peneliti tentukan berdasarkan nilai terendah dan tertinggi dari hasil angket.

Informasi mengenai hasil dari eksperimen yang telah dilakukan didapatkan melalui metode survei. Survei pada dasarnya merupakan pemeriksaan secara teliti tentang fakta atau fenomena perilaku dan sosial terhadap subyek dalam jumlah besar (Ali \& Asrori, 2014). Metode survei akan memperoleh data secara umum mengenai perkembangan kemampuan literasi masyarakat. Data tersebut diperoleh dengan menggunakan angket serta wawancara kepada beberapa informan. Selanjutnya, Suryana \& Priyatna menyatakan bahwa "Penelitian survai digunakan untuk melakukan penarikan kesimpulan secara umum (generalisasi) dari sampel yang ditentukan" (Suryana \& Priatna, 2008). Dalam penelitian ini sampel berfungsi sebagai penduga terhadap populasi. Pada Gambar 3 ditunjukkan bagan penelitian ini. 
Jurnal Pendidikan Geografi:

Kajian, Teori, dan Praktik dalam Bidang Pendidikan dan Ilmu Geografi

Tahun 24, Nomor 2, Jun 2019, Hal 132-144

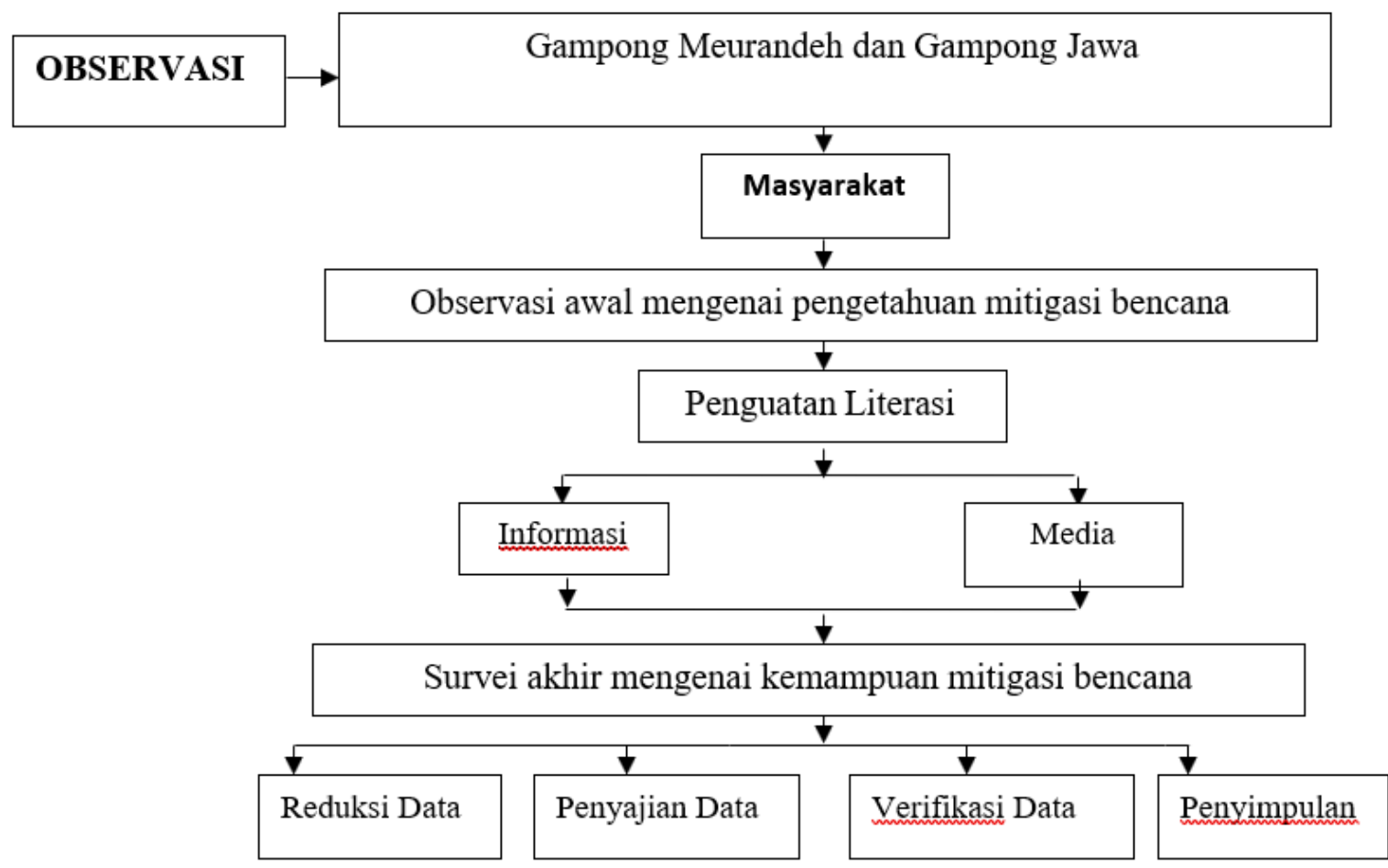

Gambar 3. Bagan Penelitian

\section{Hasil Literasi Informasi Kebencanaan}

\section{HASIL DAN PEMBAHASAN}

American Library Association (ALA) menyatakan bahwa "Information literacy is a set of abilities requiring individuals to recognize when information is needed and have the ability to locate, evaluate, and use effectively the needed information" (Literasi informasi merupakan serangkaian kemampuan yang dibutuhkan seseorang untuk menyadari kapan informasi dibutuhkan dan kemampuan untuk menempatkan, mengevaluasi, dan menggunakan informasi yang dibutuhkan secara efektif).

Pernyataan pada Asosiasi tersebut menjadi indikator pencapaian literasi kebencanaan pada penelitian ini. Hasil penelitian ini menunjukkan bahwa literasi informasi bencana dapat meningkatkan kemampuan mitigasi bencana mencapai 56\%. Meningkatnya kemampuan melalui literasi pada penelitian ini sesuai dengan hasil penelitan Susanto, Sumarmi, \& Susilo (2016) yang menyatakan bahwa "Literasi geografis menggunakan pengalaman siswa untuk memecahkan masalah kehidupan nyata sebagai platform. Para siswa juga membuat korelasi antara mitigasi bencana dan adaptasi, materi yang dibahas dalam kelas dan kehidupan seharihari mereka untuk meningkatkan kesadaran mereka terhadap bencana alam".

Untuk memperjelas mengenai peningkatan kemampuan tersebut maka akan dibahas pada beberapa bagian sebagai berikut:

\section{Identifikasi dan Penempatan Informasi}

Sebelum mengenal literasi bencana sebenarnya masyarakat Kota Langsa dalam hal ini sudah memiliki informasi mengenai bencana banjir namun belum dapat mengidentifikasi informasi tersebut dengan sempurna. Informasi yang mereka miliki masih tahap mengetahui bahwa banjir akan terjadi apabila hujan deras. Hal tersebut senada dengan hasil dari penelitian serupa pada Gampong Seulalah Kota Langsa yang menyatakan bahwa "Most of the gampong resident know that flood disaster is a threat in their environment, but their 
Jurnal Pendidikan Geografi:

Kajian, Teori, dan Praktik dalam Bidang Pendidikan dan Ilmu Geografi

Tahun 24, Nomor 2, Jun 2019, Hal 132-144

knowledge is only limited to rain as the main cause of this problem" (Afrian, Islami, Akob, Hamdani, \& Sofyan, 2018).

Informasi sederhana tersebut ternyata merupakan salah satu bentuk identifikasi dan menempatkan informasi. Hal tersebut dilakukan saat menghadapi bencana banjir. Meskipun masih sederhana yaitu berupa identifikasi mengenai waktu terjadinya banjir. Masyarakat juga telah mengetahui lokasi yang harus dituju saat banjir datang. Hal tersebut sesuai dengan penelitian yang dilakukan sebelumnya. Pada penelitian tersebut salah satu responden mengatakan bahwa "pada saat hujan deras datang maka kami akan segera mengemasi barang dan menuju ke tempat saudara. Kami akan kembali ke rumah setelah air banjir mulai surut". Sehingga dapat disimpulkan bahwa identifikasi dan penempatan masyarakat Kota Langsa yang berada di lokasi banjir sudah ada namun masih sangat sederhana. Pengetahuan awal masyarakat sebelum diberikan informasi dan setelah diberikan informasi disajikan pada Gambar 4 di bawah ini.

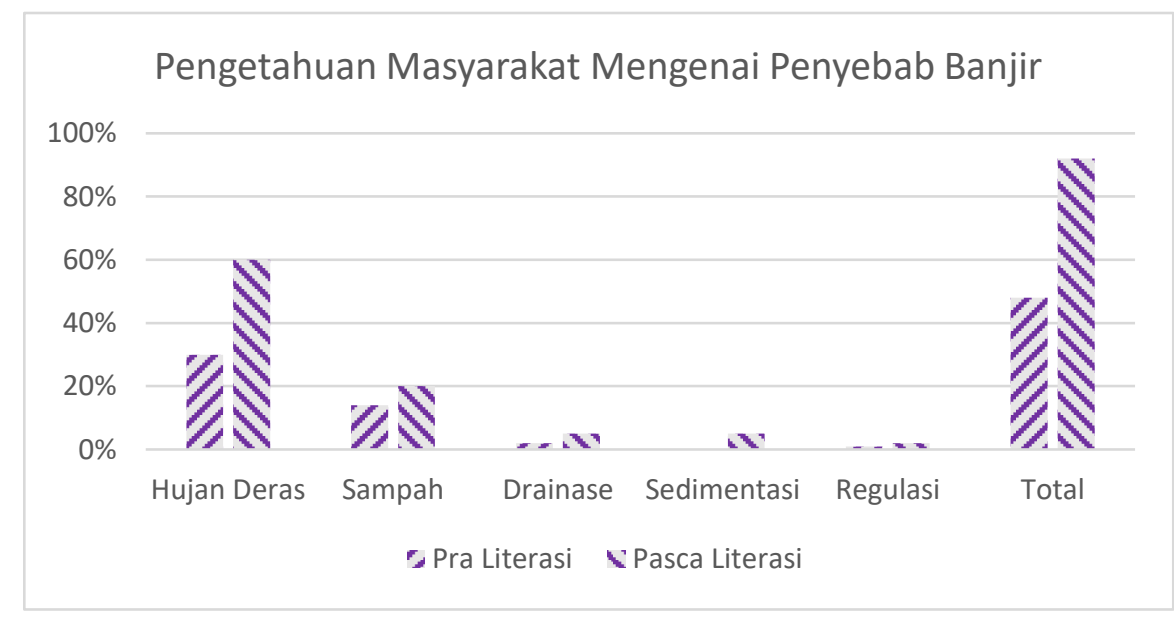

Gambar 4. Pengetahuan Masyarakat Mengenai Penyebab Banjir

Setelah diketahui kemampuan awal tentang banjir maka masyarakat diberikan perlakuan untuk meningkatkan kepahaman. Perlakuan dalam eksperimen berupa pemberian materi (ceramah) dan media tentang banjir. Perlakuan yang diberikan ternyata berhasil meningkatkan kepahaman masyarakat mengenai bencana banjir. Melalui survei diketahui bahwa kepahaman meningkat sebesar 44\% (Gambar 4). Peningkatan kepamahaman terlihat dari jawaban masyarakat yang lebih baik dari jawaban sebelumnya. Selain dapat mengidentifikasi melalui derasnya hujan, masyarakat juga dapat menyebutkan dan mengidentifikasi unsur-unsur tambahan penyebab banjir. Salah satu contoh adalah saat ditanyakan mengenai banjir, responden menyatakan bahwa "banjir bukan oleh hujan aja tapi juga oleh sampah dan parit yang penuh dengan daun".

Kemampuan masyarakat dalam mengidentifikasi dan menemukan lokasi informasi bencana sudah sangat baik, bahkan dari informasi yang telah mereka dapatkan, mereka sudah dapat mempersiapkan diri dalam menghadapi bencana yang sewaktu-waktu dapat terjadi, terterutama di daerah yang pernah atau sering mengalami bencana (Marlyono, Pasya, \& Nandi, 2016). Marno (dalam Priyowidodo \& Luik, 2013) mengemukakan "Menawi tsunami kados ten Aceh nggih dereng kedadosan. Ngih sampun ngantos. Nanging nek sanjange tiyang-tiyang sepah rumiyen, nggih kulo dikengken atos-atos nek enten toyo seganten sat sanaliko. Pasti niku bade mbekto tondo-tondo ingkang mboten nggenah" (Kalau tsunami seperti kejadian di Aceh belum pernah terjadi. Ya jangan sampai terjadi. Tetapi jika menurut ceritera orang tua-orang tua dulu, saya disuruh hati-hati kalau mendadak air laut surut. Pasti 
Jurnal Pendidikan Geografi:

Kajian, Teori, dan Praktik dalam Bidang Pendidikan dan Ilmu Geografi

Tahun 24, Nomor 2, Jun 2019, Hal 132-144

itu tanda-tanda alam yang akan membawa kejadian yang tidak diharapkan". Untuk itu, mengidentifikasi informasi lokasi bencana akan sangat berpengaruh bagi mitigasi bencana.

Namun masih terdapat juga permasalahan dalam hal regulasi. Pemerintah seperti kurang antusias dalam menyosialisasikan peraturan yang berhubungan dengan bencana banjir. Sebagai contoh tidak adanya sosialisasi mengenai dampak membuang sampah di sungai, sehingga masih ada masyarakat yang membuang sampah di sungai. Selain itu masyarakat tidak mengetahui ada atau tidaknya larangan untuk mendirikan bangunan di bantaran sungai. Padahal hal tersebut dapat memicu terjadinya banjir.

\section{Mengevaluasi}

Setelah tahap mengidentifikasi masyarakat diharuskan untuk dapat mengevaluasi keadaan sekitar sehingga mendapatkan jawaban atas hal-hal yang menjadi penyebab terjadinya banjir. Mengevaluasi bermaksud menentukan nilai dari elemen-elemen pesan, penilaian disusun dengan membandingkan elemen melalui kriteria tertentu (Adiputra, 2008). Dalam hal ini masyarakat masih kurang menilai dan mengevaluasi secara mendalam penyebab terjadinya banjir. Faktor pengetahuan diduga menjadi penyebabnya. Pengetahuan dalam hal ini berupa pengetahuan dasar mengenai penyebab terjadinya banjir seperti fungsi drainase, hal-hal yang menjadi penghalang jalannya air serta proses terjadinya hujan. Hal tersebut sesuai dengan pernyataan Iswandi (Umar, 2017) yakni "Peningkatan intensitas curah hujan, penyempitan saluran drainase, pembuangan limbah industri dan rumah tangga, sedimentasi, dan penggunaan lahan mendorong terjadinya banjir, sehingga banjir dapat menimbulkan kerugian bagi kehidupan manusia".

Hal ini diperkuat dengan hasil penelitian Marlyono et al., (2016) yang menyatakan bahwa "Kecilnya pengaruh yang dihasilkan dari mengevaluasi informasi secara kritis terhadap kesiapsiagaan masyarakat dalam menghadapi bencana disebabkan oleh kurangnya pemahaman masyarakat mengenai informasi yang didapatkan". Kurangnya pengetahuan tersebut diduga dilatarbelakangi oleh tingkat pendidikan masyarakat yang masih belum terlalu baik.

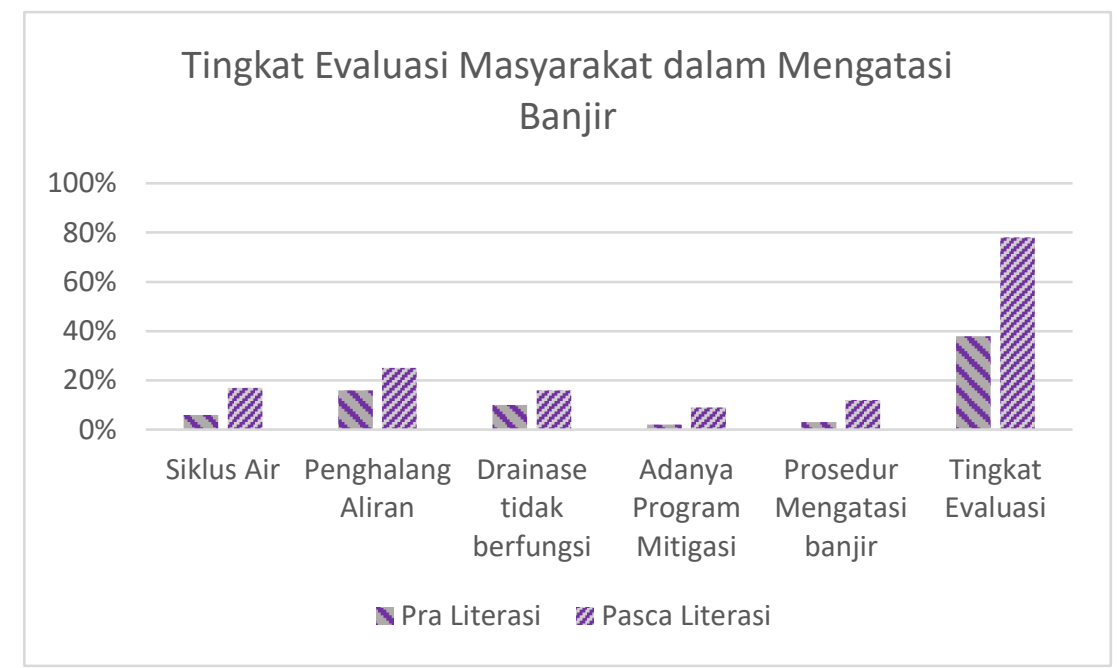

Gambar 5. Tingkat Evaluasi Masyarakat dalam Mengatasi Banjir

Hasil penelitian menyatakan bahwa terdapat peningkatan kemampuan evaluasi tercatat sebanyak 40\% (Gambar 5). Meningkatnya kemampuan evaluasi ditandai dengan adanya pengetahuan baru tentang faktor penyebab terjadinya banjir yang selama ini belum mereka ketahui. Setelah mengetahui faktor-faktor tambahan tersebut maka berakibat kepada peningkatan kemampuan evaluasi yang lebih mendalam. 
Jurnal Pendidikan Geografi:

Kajian, Teori, dan Praktik dalam Bidang Pendidikan dan Ilmu Geografi

Tahun 24, Nomor 2, Jun 2019, Hal 132-144

Masyarakat yang telah mendapatkan peningkatan kemampuan dalam mengevaluasi dapat memberikan pernyataan-pernyataan terkait masalah utama banjir. Mereka juga dapat menjawab saat diberikan pertanyaan tentang drainase, pengelolaan sampah, pendangkalan sungai serta bentuk dari program mitigasi bencana banjir di kampung mereka. Selain itu masyarakat dapat memberikan penilaian mengenai kinerja aparat desa dalam menangani bencana banjir.

Hal ini disebabkan karena masyarakat telah mendengar dari penyampaian materi serta membaca brosur dan poster. Penyampaian materi menggunakan media gambar dapat memberikan pemahaman lebih baik searah dengan teori kognitif dari pembelajaran multimedia bahwa orang memahami petunjuk yang lebih baik ketika mereka menerima kata-kata dan sesuai bantu visual bersama-sama dari pada teks saja (Brown, Haun, \& Peterson, 2014). Materi, brosur dan poster yang diberikan telah memberikan gambaran tentang siklus atau skema perputaran serta jalannya air. Masyarakat memahami penyebab siklus tersebut terganggu dan mulai memahami prosedur dalam mengatasi banjir.

\section{Mengintegrasi informasi}

Evaluasi dalam pendidikan kesiapsiagaan pencegahan bencana, mitigasi dan respons diperlukan untuk dapat memberikan pengalaman berharga serta pengembangan dikemudian hari (Chou, Yang, \& Ren, 2015). Evaluasi yang dilakukan membuat masyarakat mulai memahami bahaya banjir. Evaluasi juga diperlukan untuk dapat merancang sistem. Mereka mulai mengaitkan berbagai informasi dari identifikasi unsur-unsur penyebab banjir berupa hujan, penumpukan sampah, debit air yang tinggi, dan drainase yang terganggu. Hasil dari evaluasi berupa penyebab banjir dalam tingkat proses berupa siklus perjalanan air, drainase yang tidak berjalan dengan baik, serta proses mengatasi banjir.

Sebelum adanya pemahaman literasi masyarakat kota langsa hanya dapat bercerita tentang bencana banjir secara sederhana. Setelah mendapatkan pemahaman dan proses peningkatan literasi telah terjadi peningkatan pemahaman sebanyak 47\% (Gambar 6).

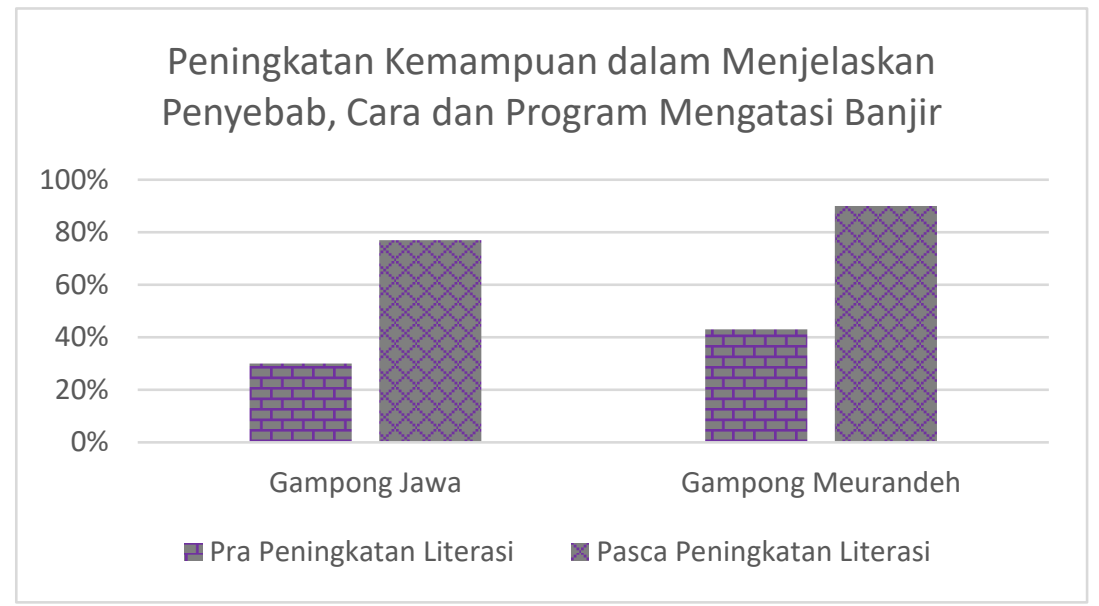

Gambar 6. Peningkatan Kemampuan dalam Menjelaskan Penyebab, cara dan Program Mengatasi banjir (Mengintegrasikan Informasi)

Masyarakat telah mendapatkan banyak informasi. Informasi yang telah didapatkan melalui proses literasi sebelumnya diintegrasikan menjadi suatu pemahaman tingkat tinggi. Pemahaman baru tersebut berupa suatu konsep utuh bagaimana banjir tersebut dapat terjadi. Pada tahap ini masyarakat telah mengerti bahwa banjir merupakan sebuah kejadian yang memiliki banyak keterkaitan. Salah satu responden berkata "Rupanya banjir bukan hanya masalah hujan, banyaknya sampah yang menghalangi jalannya air juga menjadi penyebab”. 
Jurnal Pendidikan Geografi:

Kajian, Teori, dan Praktik dalam Bidang Pendidikan dan Ilmu Geografi

Tahun 24, Nomor 2, Jun 2019, Hal 132-144

Responden lain juga mengatakan "Pantas saja Gampong sering banjir, saluran air ternyata tidak berfungsi”.

Masyarakat telah mengharapkan adanya program kesiapsiagaan menghadapi bencana. Upaya ini sangat diperlukan masyarakat untuk mengurangi risiko/dampak bencana alam, termasuk korban jiwa, kerugian harta benda, dan kerusakan lingkungan (Hidayati, 2018). Bentuk dari kesiapsiagaan yang diharapkan adalah adanya peringatan dini, perlengakapan penerangan, dan rencana tanggap darurat. Sejalan dengan ini Rosyidie (2013) menyatakan bahwa "early warning system (peringatan dini) supaya pihak yang terkait dapat melakukan antisipasi sejak dini sehingga dapat meminimalisir dampaknya". Peringatan dini dapat berasal dari hal yang sangat sederhana sampai dengan menggunakan teknologi. Seperti yang diungkapkan Adi (2013) bahwa "sistem peringatan dini dengan menggunakan alat penakar curah hujan dan alat pengukur muka air sungai". Hasil dari alat ukur tersebut dapat menentukan akankah terjadi banjir atau tidak. Sehingga informasi dapat disebarkan dengan cepat berdasarkan data tersebut.

Selain itu pendataan sumber daya pendukung yang dapat membantu kelancaran program juga harus didata. Hal tersebut sesuai dengan pernyataan Dodon (dalam Erlia, Kumalawati, \& Aristin, 2017) menyatakan bahwa dalam membahas kesiapsiagaan terdapat beberapa poin yang menjadi pokok pembahasan, antara lain: pengetahuan dan sikap terhadap bencana, rencana tanggap darurat, sistem peringatan dini, dan sumber daya pendukung.

\section{Memanfaatkan dan menginformasikan}

Indikator terakhir dalam proses peningkatan mitigasi bencana melalui literasi adalah memanfaatkan tiga indikator diatas secara maksimal. Pada tahap ini bentuk dari pemanfaatan dan menginformasikan pengetahuan mereka tentang banjir adalah berkoordinasi dengan pemerintah setempat. Koordinasi yang dilakukan adalah menyarankan pembentukan program mitigasi bencana. Selain masyarakat, Munaf (2007) menyatakan "diperlukan penyatuan derap langkah dari seluruh lembaga riset dan perguruan tinggi untuk bersamasama dan terintegrasi meningkatkan peran dalam kegiatan antisipasi penanganan bencana banjir" agar program mitigasi dapat terkonsep dan berjalan dengan baik. Program-program yang diusulkan antara lain adalah pembuatan skema tanggap darurat Gampong terhadap bencana banjir. Pada saat banjir datang masyarakat dapat melakukan tindakan yang sesuai dengan skema tersebut agar jumlah korban dapat diminimalisir.

Masyarakat juga melaksanakan program bersih-bersih desa dengan tujuan agar sistem aliran air yang selama ini tersumbat sampah dapat berfungsi dengan baik. Selain itu masyarakat juga membuat plang (tulisan) untuk tidak membuang sampah di sungai. Hal ini dimaksudkan agar tidak lagi terdapat sampah yang dapat menghalangi jalannya air sungai.

Program selanjutnya adalah penyebaran informasi mengenai bahaya banjir kepada masyarakat melalui penyuluhan-penyuluhan. Penyebaran informasi juga dilakukan dengan menginformasikan kepada masyarakat untuk rajin membaca poster di papan pengumuman. Pembicaraan antar ibu-ibu juga menjadi salah satu bentuk penyebaran informasi yang dilakukan oleh masyarakat setelah memahami tentang bahaya banjir. Hal tersebut sangat penting dikarenakan pemberdayaan publik dan diseminasi peringatan dini secara luas serta cepat pada dasarnya akan mampu menyelamatkan lebih banyak manusia (Prajarto, 2008).

Selain itu masyarakat juga dituntut untuk menyebarkan dan memahami bahwa dalam menghadapi bencana banjir harus memiliki beberapa kemampuan. Maarif (dalam Nugroho, 2012) menyatakan bahwa kemampuan untuk mengantisipasi ancaman bahaya banjir antara lain, kemampuan menghindar atau melawan bahaya banjir, kemampuan untuk mengadaptasi bencana dan dampak yang ditimbulkan, dan kemampuan untuk pulih kembali secara cepat 
Jurnal Pendidikan Geografi:

Kajian, Teori, dan Praktik dalam Bidang Pendidikan dan Ilmu Geografi

Tahun 24, Nomor 2, Jun 2019, Hal 132-144

paska kejadian bencana. Dengan tersebarnya informasi tersebut diharapkan masyarakat dapat menyiapkan kemampuan-kemapuan tersebut untuk menghadapi bahaya banjir.

\section{KESIMPULAN}

Penelitian ini bertujuan untuk memecahkan permasalahan mengenai kemampuan menghadapi bencana banjir pada masyarakat Kota Langsa. Berdasarkan hasil dari penelitian diketahui bahwa masalah kemampauan literasi kebencanaan dapat diatasi dengan memberikan berbagai macam bentuk bacaan. Bentuk dari bacaan tersebut antara lain berupa poster, komik atau selebaran. Proses peningkatan literasi informasi kebencanaan membawa peningkatan kepahaman dan kesiapsiagaan masyarakat terhadap bencana banjir. Hal tersebut terbukti pada peningkatan kemampuan masyarakat dalam mengidentifikasi faktor-faktor yang menyebabkan terjadinya banjir. Selain itu masyarakat juga telah dapat mengevaluasi mengenai penyebab banjir seperti permasalahan pada pengelolaan sampah dan drainase.

Peningkatan juga terjadi pada proses pengintegrasian informasi. Masyarakat mulai dapat memberikan pernyataan mengenai solusi dan sistem yang harus dibuat serta dilaksanakan agar bencana banjir dapat teratasi. Selain itu, masyarakat telah berkeinginan untuk melakukan perancanangan skema tanggap darurat Gampong terhadap bencana banjir. Penyebaran informasi juga dilakukan dengan pemberitahuan mengenai adanya poster dan komik tentang banjir. Selain itu infromasi juga disebarkan melalui pembicaraan oleh ibu-ibu rumah tangga.

\section{DAFTAR RUJUKAN}

Adi, S. (2013). Karakterisasi bencana banjir bandang di Indonesia. Jurnal Sains dan Teknologi Indonesia, 15(01), 42-51.

Adiputra, W. M. (2008). Literasi media dan interpretasi bencana. JSP, Jurnal Ilmu Sosial dan Ilmu Politik, 11(03), 01-20.

Afrian, R., Islami, Z. R., Akob, B., Hamdani, \& Sofyan. (2018). Analysis of flood disaster response preparedness in Gampong Seulalah Langsa Lama Sub-District Langsa City. MATEC Web of Conferences, 229, 01008. https://doi.org/10.1051/matec conf $/ 201822901008$

Ali, M., \& Asrori, M. (2014). Metode dan aplikasi riset pendidikan. Bumi Aksara.

Badan Nasional Penganggulangan Bencana. (n.d.). Peta indeks resiko banjir Provinsi Aceh. Tematik, Aceh: Badan Nasional Penanggulangan Bencana.

Boy, B. (2018, November 22). Walhi: Aceh darurat bencana. Habadaily.Com.

Brown, L. M., Haun, J. N., \& Peterson, L. (2014). A Proposed disaster literacy model. Disaster Medicine and Public Health Preparedness, 8(03), 267-275. https://doi.org/10.1017/dmp.2014.43

Chou, J.-S., Yang, K.-H., \& Ren, T.-C. (2015). Ex-post evaluation of preparedness education in disaster prevention, mitigation and response. International Journal of Disaster Risk Reduction, 12, 188-201. https://doi.org/10.1016/j.ijdrr.2015.01.002

Dedek, D. (2017, May 19). Puluhan rumah di Langsa terendam banjir. GoAceh.Co.

Erlia, D., Kumalawati, R., \& Aristin, N. F. (2017). Analisis kesiapsiagaan masyarakat dan pemerintah menghadapi bencana banjir di Kecamatan Martapura Barat Kabupaten Banjar. JPG (Jurnal Pendidikan Geografi), 04(03), 15-24.

Hafida, S. H. N. (2018). Urgensi pendidikan kebencanaan bagi siswa sebagai upaya mewujudkan generasi tangguh bencana. JPIS, Jurnal Pendidikan Dan Ilmu Sosial, $28(02), 1-10$.

Hidayati, D. (2018). Kesiapsiagaan masyarakat: Paradigma baru pengelolaan bencana alam. JKI, Jurnal Kependudukan Indonesia, 03(01), 69-84. 
Jurnal Pendidikan Geografi:

Kajian, Teori, dan Praktik dalam Bidang Pendidikan dan Ilmu Geografi

Tahun 24, Nomor 2, Jun 2019, Hal 132-144

Marlyono, S. G., Pasya, G. K., \& Nandi, N. (2016). Pengaruh literasi informasi bencana terhadap kesiapsiagaan masyarakat dalam menghadapi bencana di Provinsi Jawa Barat. Gea, Jurnal Pendidikan Geografi, 16(02), 116-123.

Munaf, D. R. (2007). Prinsip interkoneksi informasi dalam penanganan bencana banjir. Jurnal Sosioteknologi, 06(10), 156-160.

Prajarto, N. (2008). Bencana, informasi dan keterlibatan media. JSP, Jurnal Ilmu Sosial Dan Ilmu Politik, 11(03), 01-24.

Priyowidodo, G., \& Luik, J. E. (2013). Literasi mitigasi bencana tsunami untuk masyarakat pesisir di Kabupaten Pacitan Jawa Timur. EKOTRANS, 13(01), 47-61.

Rosyidie, A. (2013). Banjir: Fakta dan dampaknya, serta pengaruh dari perubahan guna lahan. Jurnal Perencanaan Wilayah Dan Kota, 24(03), 241-249.

Shah, A. A., Ye, J., Abid, M., Khan, J., \& Amir, S. M. (2018). Flood hazards: Household vulnerability and resilience in disaster-prone districts of Khyber Pakhtunkhwa Province, Pakistan. Natural Hazards, 93(1), 147-165. https://doi.org/10.1007/s11069-018-3293-0

Suganda, E., Yatmo, Y. A., \& Atmodiwirjo, P. (2009). Pengelolaan lingkungan dan kondisi masyarakat pada wilayah Hilir Sungai. Makara, Sosial Humaniora, 13(02), 143-153.

Suryana, Y., \& Priatna, T. (2008). Metode penelitian pendidikan. Sahifa.

Susanto, A., Sumarmi, S., \& Susilo, S. (2016). Improving natural disaster mitigation and adaptation using geographic literacy. Mediterranean Journal of Social Sciences, 7(6), 333-338.

Umar, I. (2017). Prioritas pengembangan kawasan permukiman pada wilayah rawan banjir di Kota Padang, Provinsi Sumatera Barat. Majalah Ilmiah Globe, 19(1), 83. https://doi.org/10.24895/MIG.2017.19-1.537

Umum, D. P. (2015). Strategi sanitasi Kota Langsa. Langsa: Dinas Pekerjaan Umum.

Yogiesti, V., Hariyani, S., \& Sutikno, F. R. (2010). Pengelolaan sampah terpadu berbasis masyarakat Kota Kediri. Jurnal Tata Kota Dan Daerah, 02(02), 95-102. 